\title{
The phosphoinositide 3-kinase pathway and therapy resistance in cancer
}

\author{
Kristin K. Brown* and Alex Toker*
}

Address: Department of Pathology and Cancer Center, Beth Israel Deaconess Medical Center, Harvard Medical School, 330 Brookline Avenue, EC/CLS 633A, Boston, MA 02215, USA

* Corresponding authors: Kristin K. Brown (kkbrown@bidmc.harvard.edu); Alex Toker (atoker@bidmc.harvard.edu)

Fl000Prime Reports 2015, 7:13 (doi:10.12703/P7-13)

All FI000Prime Reports articles are distributed under the terms of the Creative Commons Attribution-Non Commercial License (http://creativecommons.org/licenses/by-nc/3.0/legalcode), which permits non-commercial use, distribution, and reproduction in any medium, provided the original work is properly cited.

The electronic version of this article is the complete one and can be found at: http://fl000.com/prime/reports/b/7//3

\begin{abstract}
The phosphoinositide 3-kinase ( $\mathrm{PI} \mathrm{K}$ )/Akt/mechanistic target of rapamycin ( $\mathrm{mTOR}$ ) signaling network is a master regulator of processes that contribute to tumorigenesis and tumor maintenance. The PI3K pathway also plays a critical role in driving resistance to diverse anti-cancer therapies. This review article focuses on mechanisms by which the PI3K pathway contributes to therapy resistance in cancer, and highlights potential combination therapy strategies to circumvent resistance driven by PI3K signaling. In addition, resistance mechanisms that limit the clinical efficacy of small molecule inhibitors of the PI3K pathway are discussed.
\end{abstract}

\section{Introduction}

\section{The PI3K/Akt/mTOR signaling pathway}

Signaling via the PI3K/Akt/mTOR pathway has been the subject of a number of in-depth reviews and will only be briefly summarized here. In response to the activation of receptor tyrosine kinases (RTKs) and G protein-coupled receptors (GPCRs), the lipid kinase PI3K phosphorylates phosphatidylinositol $(4,5)$-bisphosphate $\left(\mathrm{PI}[4,5] \mathrm{P}_{2}\right)$ to synthesize the second messenger phosphatidylinositol (3,4,5)-trisphosphate $\left(\mathrm{PIP}_{3}\right) . \mathrm{PIP}_{3}$ recruits Akt to the plasma membrane where it is phosphorylated and activated by phosphoinositide-dependent kinase-1 (PDK-1) and mTOR complex 2 (mTORC2). Activated Akt subsequently phosphorylates numerous substrates that promote tumorigenesis, including tuberous sclerosis complex 2 (TSC2), which in turn activates mTOR complex 1 (mTORC1). Signal termination of the PI3K/Akt/mTOR pathway is primarily accomplished by the tumor suppressor phosphatase and tensin homolog (PTEN), which catalyzes the dephosphorylation of $\mathrm{PIP}_{3}$ back to $\mathrm{PI}(4,5) \mathrm{P}_{2}$.

\section{The PI3K pathway in cancer}

Dysregulated signaling through the PI3K pathway is implicated in virtually all human cancers. Amplification and gain-of-function mutations of the PIK3CA gene encoding the catalytic $\mathrm{p} 110 \alpha$ subunit of PI3K are extremely prevalent in cancer, and promote increased signaling through the PI3K pathway. Indeed, PIK3CA is one of the most frequently mutated oncogenes in human tumors [1-4]. Loss-of-function mutations, deletion, and decreased expression levels of PTEN are also frequently observed in human tumors [5]. Even in the absence of alterations in PI3K or PTEN, disruption of the PI3K pathway can occur as a consequence of a multitude of lesions, including amplification or mutation of upstream RTKs, Akt amplification or mutation [6], and loss of inositol polyphosphate-4-phosphatase (INPP4B) that converts phosphatidylinositol $(3,4)$ bisphosphate (PI[3,4] $\left.\mathrm{P}_{2}\right)$ to $\mathrm{PI}(3) \mathrm{P}[7]$.

Signaling through the PI3K/Akt/mTOR pathway contributes to tumorigenesis through effects on a myriad of cellular processes, including apoptosis, proliferation, motility, and metabolism. The PI3K pathway is now also recognized as a major driver of resistance to diverse anticancer therapeutics. The frequency of PI3K/Akt/mTOR hyperactivation in cancer, coupled with the critical role of $\mathrm{PI} 3 \mathrm{~K}$ signaling in tumorigenesis and anti-cancer therapy 
resistance, has culminated in significant efforts to generate small molecule inhibitors to target this pathway.

\section{Contribution of the PI3K pathway to therapy resistance}

The PI3K pathway and resistance to chemotherapy

Despite significant advances in the development of molecularly targeted therapies, traditional cytotoxic chemotherapy drugs remain an integral component of treatment regimens for most types of cancer. However, the clinical efficacy of diverse chemotherapy agents is undermined by resistance mechanisms. The PI3K pathway has been recognized for some time as a major contributor to chemotherapy resistance, with activation of the pathway being associated with reduced sensitivity to chemotherapy drugs including the topoisomerase II inhibitor doxorubicin and the mitotic inhibitor paclitaxel [8-10]. The mechanisms that contribute to chemotherapy resistance downstream of PI3K signaling are diverse; however, the elevated expression of anti-apoptotic proteins, including myeloid cell leukemia 1 (Mcl-1), is frequently observed [11,12]. It has also become apparent that DNA damage triggered by some chemotherapy drugs, including doxorubicin, can trigger the phosphorylation of Akt to promote survival and therapy resistance [13-15]. The critical role of the PI3K pathway in chemotherapy resistance has been confirmed by studies showing significant synergy between PI3K pathway inhibitors and chemotherapy in preclinical models $[15,16]$. Clinical trials examining the efficacy of combination treatment with chemotherapy and PI3K pathway inhibitors are in progress (https://clinicaltrials.gov).

\section{The PI3K pathway and resistance to endocrine therapy}

Endocrine therapies, which interfere with estrogen receptor or androgen receptor signaling, are frequently used in the management of breast and prostate cancers. Hyperactivation of the PI3K pathway has been associated with resistance to endocrine therapies, including the estrogen receptor antagonist tamoxifen $[8,17]$. Furthermore, breast and prostate cancer cells that have adapted to endocrine therapy rely on PI3K signaling for survival, and preclinical studies indicate that inhibition of the PI3K pathway can circumvent resistance to endocrine therapy $[17,18]$. The phase III BOLERO-2 trial highlighted the contribution of PI3K signaling to endocrine therapy resistance by demonstrating that combination therapy with the mTOR inhibitor everolimus and the aromatase inhibitor exemestane (which inhibits estrogen biosynthesis) improved progression-free survival, when compared to exemestane monotherapy [19]. In addition, clinical benefit was observed in a multicenter phase Ib study investigating combination therapy with the PI3K inhibitor NVPBKM120 and the aromatase inhibitor letrozole in patients with metastatic, estrogen receptor-positive breast cancer [20]. While breast cancer patient data have primarily associated the activation of the PI3K pathway with poor outcome following endocrine therapy, it should be noted that mutations in PIK3CA have been associated with favorable prognosis in several studies [21-23]. These apparently contradictory findings are suggestive of a dual role for the PI3K pathway in estrogen receptor-positive breast cancer. Indeed, Mayer and Arteaga hypothesize that, in early estrogen receptor-positive breast cancers, PIK3CA mutations may be a marker of highly hormone-dependent, indolent tumors, whereas in late estrogen receptorpositive breast cancers (selected by primary endocrine therapy), PIK3CA mutations provide a mechanism of endocrine therapy resistance and are therefore associated with poor outcome [24].

\section{The PI3K pathway and resistance to RTK inhibitors}

Overexpression or mutational activation of RTKs is frequently observed in cancer and thus has rendered RTKs important therapeutic targets for cancer therapy. PI3K pathway activity has been shown to predict a response to RTK inhibitors, and to contribute to resistance to RTK inhibitors (including the epidermal growth factor receptor inhibitor gefitinib and the antiHER2 antibody trastuzumab) [25-27]. Indeed, most models of acquired resistance to RTK inhibitors demonstrate persistent PI3K signaling. In some cancers, multiple RTKs drive the activation of the PI3K pathway, and these cancers are therefore resistant to RTK inhibitor monotherapy $[28,29]$. Combination therapy with agents targeting multiple RTKs, or RTKs in combination with PI3K pathway inhibitors, may circumvent RTK inhibitor resistance [30]. Indeed, early signs of clinical activity have recently been observed in a phase Ib study investigating combination therapy with the PI3K inhibitor NVP-BKM120 and trastuzumab in patients with HER2-positive advanced/metastatic breast cancer resistant to trastuzumab monotherapy [31].

\section{The PI3K pathway and resistance to agents targeting the MAPK pathway}

Aberrant signaling through the mitogen-activated protein kinase (MAPK) pathway plays a critical role in cancer development and progression, and significant effort has been made to develop MAPK pathway inhibitors. Extensive crosstalk exists between MAPK and PI3K signaling pathways and therefore, not surprisingly, enhanced PI3K signaling has been associated with BRAF inhibitor resistance in cell lines and human tumors [32]. Interestingly, the MEK inhibitor PD-0325901 has been proposed to enhance PI3K signaling by disrupting the membrane localization of PTEN [33]. Synergy between MAPK inhibitors and PI3K pathway inhibitors has been observed in many reports $[32,34,35]$. 
The PI3K pathway and resistance to anti-angiogenic therapy Anti-angiogenic therapies target vessels that grow to provide oxygen and nutrients to actively proliferating tumors. The most established approach for disrupting tumor angiogenesis is the inhibition of vascular endothelial growth factor (VEGF) signaling. Upregulation of PI3K pathway activity, particularly mTOR signaling, has been observed in breast cancer xenografts exposed to the anti-VEGF-A antibody bevacizumab and, as a consequence, combination therapy with bevacizumab and the PI3K/mTOR inhibitor NVP-BEZ235 enhances anti-tumor effects in preclinical models [36]. In addition, a recent study has revealed that disruption of the interaction between Ras and the $\mathrm{p} 110 \alpha$ subunit of PI3K can reduce tumor-induced angiogenesis, at least in part by inhibiting VEGF-A signaling [37].

\section{The PI3K pathway and resistance to immunotherapy}

In recent years, there has been an emerging interest in modulating the immune system for cancer therapy, and strategies that stimulate the immune system to recognize and attack cancer cells have been developed. The ability of the PI3K pathway to mediate resistance to immunotherapy has been associated with the increased expression of anti-apoptotic proteins including $\mathrm{Mcl}-1$ $[38,39]$. In addition, PI3K pathway hyperactivity induced by loss of PTEN is associated with the elevated expression of programmed death-ligand 1 (PD-L1), which plays a major role in suppressing the immune system [40,41]. There is some evidence that PI3K inhibitors can dramatically heighten the response to cancer immunotherapy [42] and a recent study demonstrated that PI-3065, a small molecule inhibitor of PI3Kס, disrupts tumor-induced immune tolerance and promotes antitumor immunity [43].

\section{The PI3K pathway and resistance to hedgehog pathway inhibitors}

Aberrant activation of the hedgehog pathway is associated with cancer, especially basal cell carcinoma and medulloblastoma. The hedgehog pathway is activated by the binding of the hedgehog ligand to the transmembrane receptor Patched, which prevents Patched from repressing the GPCR-like molecule Smoothened (SMO). A recent study demonstrated that PI3K target genes are enriched in mouse medulloblastoma tumors resistant to the SMO antagonist NVP-LDE225, and combination treatment with NVP-LDE225 and the PI3K inhibitor NVP-BKM120, or with NVP-LDE225 and the PI3K/mTOR inhibitor NVP-BEZ235, can suppress the emergence of drug resistance [44].

\section{Resistance to PI3K pathway inhibitors}

There are currently more than 30 drugs and five classes of PI3K/Akt/mTOR pathway inhibitors (PI3K inhibitors,
PI3K/mTOR dual inhibitors, Akt inhibitors, mTORC catalytic inhibitors and rapamycin analogues) in clinical trials for cancer therapy [45]. Despite the enormous promise of targeting the PI3K pathway for cancer therapy, to date, the responses of solid tumors to PI3K pathway inhibitor monotherapy have been disappointing and drug resistance mechanisms have rapidly emerged. Broadly speaking, mechanisms of resistance to PI3K pathway inhibitors involve the incomplete inhibition of PI3K pathway activity, reactivation of the PI3K pathway, or activation of alternate pro-survival pathways (Figure 1).

\section{Insufficient inhibition of the PI3K pathway promotes resistance}

PI3K resistance mechanisms can arise through insufficient blockade of PI3K pathway activity. Indeed, it has been proposed that poor responses to PI3K inhibition in clinical trials could result from the inability to adequately inhibit PI3K signaling due to dose-limiting toxicities. For example, the concentrations of NVP-BKM120 required to fully inhibit PI3K activity are toxic, due to off-target effects on tubulin [46]. Studies have also revealed that considerable Akt and mTORC1 activity can be maintained despite inhibition of PI3K $[47,48]$. Therefore, simultaneous inhibition of PI3K and mTORC1, or of PI3K and CDK4/6-Cyclin D complex (which is regulated by mTORC1) has been shown to be highly efficacious in vitro and in xenograft models $[47,48]$.

\section{Reactivation of the PI3K pathway promotes resistance}

PI3K pathway inhibitor resistance can arise via mechanisms that promote the reactivation of PI3K signaling. For example, inhibition of RTKs, PI3K or Akt induces the expression and activation of multiple RTKs by relieving mTORC1 feedback suppression of RTKs and stimulating FOXO-dependent activation of RTK expression [49-51]. Similarly, inhibition of mTOR induces PI3K signaling through the induction of RTKs [52]. Dual inhibition of PI3K and mTOR also increases activation of JAK2/STAT5 to promote the reactivation of Akt [53]. As a consequence, combination therapy with the $\mathrm{PI} 3 \mathrm{~K} / \mathrm{mTOR}$ inhibitor NVP-BEZ235 and the JAK2 inhibitor NVPBSK805 reduces tumor growth and enhances survival. Furthermore, the amplification of a mutant PIK3CA allele was observed in a breast cancer cell line chronically exposed to the PI3K inhibitor GDC-0941 [54]. In this study, PIK3CA amplification resulted in the significant upregulation of PI3K signaling and restored proliferative capacity at clinically relevant concentrations of GDC0941. Whether or not PI3K copy number variation occurs in patients treated with PI3K inhibitors remains to be determined. Recently, resistance to the mTOR inhibitor everolimus was attributed to the acquisition of mTOR mutations that confer resistance to allosteric 
Figure I. Mechanisms that promote resistance to PI3K pathway inhibition

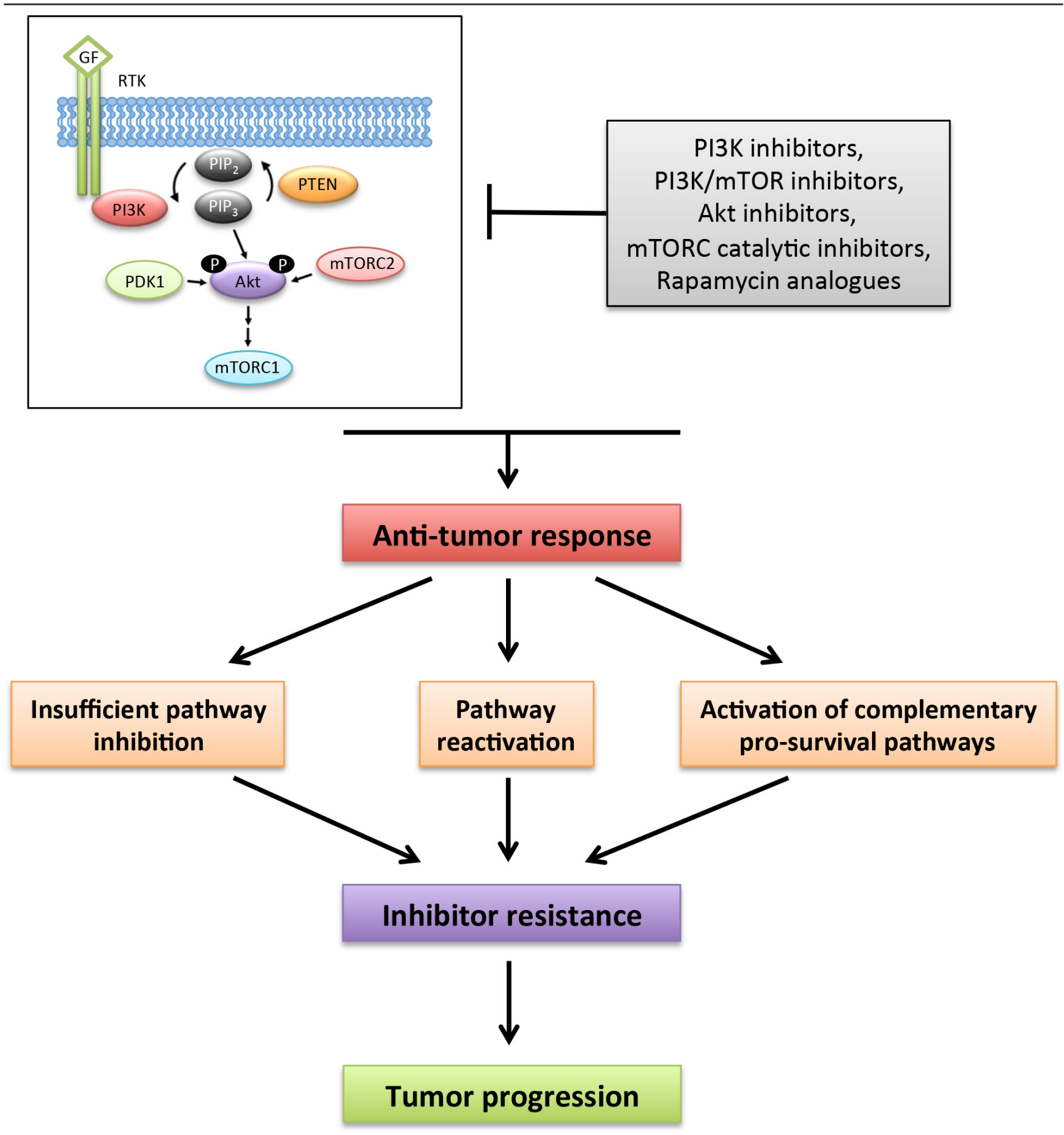

More than 30 small molecule inhibitors targeting the phosphoinositide 3-kinase (PI3K) pathway are currently in clinical trials for cancer therapy. PI3K inhibition can promote anti-tumor responses, but drug resistance mechanisms frequently limit the efficacy of PI3K pathway inhibition. Mechanisms of resistance to the PI3K pathway inhibitors involve the incomplete inhibition of pathway activity, reactivation of the PI3K pathway or activation of alternative pro-survival pathways.

GF, growth factor; mTOR, mammalian target of rapamycin; mTORCI, mTOR complex I; mTORC2, mTOR complex 2; PDK-I, phosphoinositide-dependent kinase-I; PIP 3 , phosphatidylinositol (3,4,5)-trisphosphate; PTEN, phosphatase and tensin homolog; PI3K, phosphoinositide 3-kinase; RTK, receptor tyrosine kinase. 
mTOR inhibition [55,56]. Interestingly, the mTOR mutants identified in both studies retain sensitivity to mTOR kinase inhibitors.

\section{Activation of alternate pro-survival pathways promotes resistance}

Inhibition of the PI3K pathway frequently leads to enhanced signaling through complementary pro-survival signaling pathways. For example, the inhibition of the PI3K pathway activates the MAPK pathway and promotes MAPK dependency in mouse models of cancer and in human tumors $[57,58]$. Consequently, pharmacological inhibition of the MAPK pathway enhances the anti-tumor effects of PI3K pathway inhibition. Ribosomal S6-kinase (RSK) also promotes survival under conditions of PI3K/mTOR inhibition and RSK-specific inhibitors can overcome resistance phenotypes in patient-derived xenograft models [59]. In addition, mouse mammary tumors driven by mutant PIK3CA recur after the inactivation of the mutant kinase and are associated with the amplification of $M y c$, which promotes tumor survival independently of the PI3K pathway [60]. Indeed, $M y c$ amplification has been shown to confer resistance to $\mathrm{PI} 3 \mathrm{~K}$ pathway inhibitors in multiple studies $[61,62]$.

\section{Additional strategies to circumvent resistance mechanisms driven by the PI3K pathway and enhance the clinical efficacy of PI3K pathway inhibitors}

A number of combination therapy strategies have been identified in preclinical models of therapy resistance driven by the PI3K pathway, and additional combinations have been proposed. For example, an obvious approach to sensitize cancer cells to PI3K pathway inhibitors is to disrupt pathways that prevent cell death. Indeed, the combined inhibition of PI3K/mTOR and the anti-apoptotic protein $\mathrm{Bcl}-2$ has been shown to prevent resistance to PI3K/mTOR inhibitors [63]. Another potential combination therapy approach relies on the contribution of the PI3K pathway in maintaining genomic stability, with recent studies demonstrating that PI3K inhibitors can increase DNA damage and sensitize cells to inhibitors of poly (ADPribose) polymerase (PARP), which plays a critical role in regulating the cellular response to DNA damage [64-66].

\section{Conclusions}

Therapy resistance is critical to tumor maintenance and severely limits cancer patient survival. As outlined here, the PI3K pathway has emerged as a major driver of resistance to diverse anti-cancer agents. PI3K pathway inhibitor combination therapy strategies have been devised to circumvent resistance driven by PI3K signaling and many show promise in both the pre-clinical and clinical setting. The therapeutic efficacy of numerous PI3K pathway inhibitors has also been limited by resistance mechanisms. It is therefore essential that mechanisms contributing to the ability of the PI3K pathway to promote therapy resistance, as well as mechanisms that drive PI3K pathway inhibitor resistance, continue to be elucidated. This information will enable rational combination therapies to be developed and will also identify biomarkers for patient selection.

\section{Abbreviations}

GPCR, G protein-coupled receptor; INPP4B, inositol polyphosphate-4-phosphatase; MAPK, mitogenactivated protein kinase; mTOR, mammalian target of rapamycin; mTORC1, mammalian target of rapamycin complex 1 ; mTORC2, mammalian target of rapamycin complex 2; PARP, poly (ADP-ribose) polymerase; PDK-1, phosphoinositide-dependent kinase-1; PD-L1, programmed death-ligand $1 ; \operatorname{PI}(3,4) \mathrm{P}_{2}$, phosphatidylinositol (3,4)-bisphosphate; PI3K, phosphoinositide 3-kinase; PI3P, phosphatidylinositol 3-phosphate; $\mathrm{PI}(4,5) \mathrm{P}_{2}$, phosphatidylinositol $(4,5)$-bisphosphate; $\mathrm{PIP}_{3,}$, phosphatidylinositol (3,4,5)-trisphosphate; PTEN, phosphatase and tensin homolog; RSK, ribosomal S6 kinase; RTK, receptor tyrosine kinase; TSC2, tuberous sclerosis complex 2; VEGF, vascular endothelial growth factor.

\section{Disclosures}

The authors declare that they have no disclosures.

\section{References}

I. Comprehensive molecular portraits of human breast tumours. Nature 2012, 490:61-70.

2. Comprehensive molecular profiling of lung adenocarcinoma. Nature 20 I4, 5 I I:543-50.

3. Kandoth C, Schultz N, Cherniack AD, Akbani R, Liu Y, Shen H, Robertson AG, Pashtan I, Shen R, Benz CC, Yau C, Laird PW, Ding L, Zhang W, Mills GB, Kucherlapati R, Mardis ER, Levine DA: Integrated genomic characterization of endometrial carcinoma. Nature 2013, 497:67-73.

FlOOOPrime RECOMMENDED

4. Comprehensive molecular characterization of human colon and rectal cancer. Nature 2012, 487:330-7.

FlOOOPrime

RECOMMENDED

5. Hollander MC, Blumenthal GM, Dennis PA: PTEN loss in the continuum of common cancers, rare syndromes and mouse models. Nature reviews. Cancer 201 I, I I:289-30 I.

6. Carpten JD, Faber AL, Horn C, Donoho GP, Briggs SL, Robbins CM, Hostetter G, Boguslawski S, Moses TY, Savage S, Uhlik M, Lin A, Du J, Qian Y, Zeckner DJ, Tucker-Kellogg G, Touchman J, Patel K, Mousses S, Bittner M, Schevitz R, Lai MT, Blanchard KL, Thomas JE: A transforming mutation in the pleckstrin homology domain of AKTI in cancer. Nature 2007, 448:439-44. FlOOPrime RECOMMENDED

7. Gewinner C, Wang ZC, Richardson A, Teruya-Feldstein J, Etemadmoghadam D, Bowtell D, Barretina J, Lin WM, Rameh L, 
Salmena L, Pandolfi PP, Cantley LC: Evidence that inositol polyphosphate 4-phosphatase type II is a tumor suppressor that inhibits PI3K signaling. Cancer cell 2009, 16: I 15-25.

\section{FlOOOPrime}

\section{RECOMMENDED}

8. Clark AS, West K, Streicher S, Dennis PA: Constitutive and inducible Akt activity promotes resistance to chemotherapy, trastuzumab, or tamoxifen in breast cancer cells. Molecular cancer therapeutics 2002, I:707-17.

9. VanderWeele DJ, Zhou R, Rudin CM: Akt up-regulation increases resistance to microtubule-directed chemotherapeutic agents through mammalian target of rapamycin. Molecular cancer therapeutics 2004, 3:1605-13.

10. Kandel ES, Skeen J, Majewski N, Di Cristofano A, Pandolfi PP, Feliciano CS, Gartel A, Hay N: Activation of Akt/protein kinase B overcomes a $\mathbf{G}(2) / \mathrm{m}$ cell cycle checkpoint induced by DNA damage. Molecular and cellular biology 2002, 22:783I-4I.

\section{FlOOOPrime \\ RECOMMENDED}

II. Wendel H, de Stanchina E, Fridman JS, Malina A, Ray S, Kogan S, Cordon-Cardo C, Pelletier J, Lowe SW: Survival signalling by Akt and elF4E in oncogenesis and cancer therapy. Nature 2004, 428:332-7.

\section{FlOOOPrime \\ RECOMMENDED}

12. Mills JR, Hippo Y, Robert F, Chen Samuel MH, Malina A, Lin C, Trojahn U, Wendel H, Charest A, Bronson RT, Kogan SC, Nadon R, Housman DE, Lowe SW, Pelletier J: mTORCI promotes survival through translational control of Mcl-I. Proceedings of the National Academy of Sciences of the United States of America 2008, 105: 10853-8.

13. Bozulic L, Surucu B, Hynx D, Hemmings BA: PKBalpha/Aktl acts downstream of DNA-PK in the DNA double-strand break response and promotes survival. Molecular cell 2008, 30:203-13.

\section{FIOOOPRime
RECOMMENDED}

14. Liu P, Begley M, Michowski W, Inuzuka H, Ginzberg M, Gao D, Tsou P, Gan W, Papa A, Kim BM, Wan L, Singh A, Zhai B, Yuan M, Wang Z, Gygi SP, Lee TH, Lu K, Toker A, Pandolfi PP, Asara JM, Kirschner MW, Sicinski P, Cantley L, Wei W: Cell-cycle-regulated activation of Akt kinase by phosphorylation at its carboxyl terminus. Nature 2014, 508:541-5.

\section{FlOOOPrime RECOMMENDED}

15. Wallin JJ, Guan J, Prior WW, Edgar KA, Kassees R, Sampath D, Belvin M, Friedman LS: Nuclear phospho-Akt increase predicts synergy of PI3K inhibition and doxorubicin in breast and ovarian cancer. Science translational medicine 2010, 2:48ra66.

\section{FlOOOPrime}

16. Hirai H, Sootome H, Nakatsuru Y, Miyama K, Taguchi S, Tsujioka K, Ueno Y, Hatch H, Majumder PK, Pan B, Kotani H: MK-2206, an allosteric Akt inhibitor, enhances antitumor efficacy by standard chemotherapeutic agents or molecular targeted drugs in vitro and in vivo. Molecular cancer therapeutics 2010, 9:1956-67.

17. Miller TW, Hennessy BT, González-Angulo AM, Fox EM, Mills GB, Chen H, Higham C, García-Echeverría C, Shyr Y, Arteaga CL: Hyperactivation of phosphatidylinositol-3 kinase promotes escape from hormone dependence in estrogen receptorpositive human breast cancer. The Journal of clinical investigation 2010, I 20:2406-13.

18. Carver BS, Chapinski C, Wongvipat J, Hieronymus $\mathrm{H}$, Chen $\mathrm{Y}$, Chandarlapaty S, Arora VK, Le C, Koutcher J, Scher H, Scardino PT, Rosen N, Sawyers CL: Reciprocal feedback regulation of PI3K and androgen receptor signaling in PTEN-deficient prostate cancer. Cancer cell 20II, 19:575-86.

\section{FlOOOPrime}

19. Baselga J, Campone M, Piccart M, Burris HA, Rugo HS, Sahmoud T, Noguchi S, Gnant M, Pritchard KI, Lebrun F, Beck JT, Ito Y, Yardley D, Deleu I, Perez A, Bachelot T, Vittori L, Xu Z, Mukhopadhyay P, Lebwohl D, Hortobagyi GN: Everolimus in postmenopausal hormone-receptor-positive advanced breast cancer. The New England journal of medicine 2012, 366:520-9.

\section{FlOOOPrime \\ RECOMMENDED}

20. Mayer IA, Abramson VG, Isakoff SJ, Forero A, Balko JM, Kuba MG, Sanders ME, Yap JT, Van den Abbeele Annick D, Li Y, Cantley LC, Winer E, Arteaga CL: Stand up to cancer phase Ib study of panphosphoinositide-3-kinase inhibitor buparlisib with letrozole in estrogen receptor-positive/human epidermal growth factor receptor 2-negative metastatic breast cancer. Journal of clinical oncology: official journal of the American Society of Clinical Oncology 20I4, 32: I202-9.

21. Loi S, Haibe-Kains B, Majjaj S, Lallemand F, Durbecq V, Larsimont D, Gonzalez-Angulo AM, Pusztai L, Symmans WF, Bardelli A, Ellis P, Tutt Andrew NJ, Gillett CE, Hennessy BT, Mills GB, Phillips WA, Piccart MJ, Speed TP, McArthur GA, Sotiriou C: PIK3CA mutations associated with gene signature of low $M T O R C I$ signaling and better outcomes in estrogen receptor-positive breast cancer. Proceedings of the National Academy of Sciences of the United States of America 2010, 107:10208-13.

22. Ellis MJ, Lin L, Crowder R, Tao Y, Hoog J, Snider J, Davies S, DeSchryver K, Evans DB, Steinseifer J, Bandaru R, Liu W, Gardner H, Semiglazov V, Watson M, Hunt K, Olson J, Baselga J: Phosphatidylinositol-3-kinase alpha catalytic subunit mutation and response to neoadjuvant endocrine therapy for estrogen receptor positive breast cancer. Breast cancer research and treatment 2010, I 19:379-90.

23. Sabine VS, Crozier C, Brookes CL, Drake C, Piper T, van de Velde Cornelis JH, Hasenburg A, Kieback DG, Markopoulos C, Dirix L, Seynaeve C, Rea DW, Bartlett John MS: Mutational Analysis of PI3K/AKT Signaling Pathway in Tamoxifen Exemestane Adjuvant Multinational Pathology Study. Journal of clinical oncology: official journal of the American Society of Clinical Oncology 2014.

24. Mayer IA, Arteaga CL: PIK3CA Activating Mutations: A Discordant Role in Early Versus Advanced Hormone-Dependent Estrogen Receptor-Positive Breast Cancer? Journal of clinical oncology: official journal of the American Society of Clinical Oncology 2014.

25. Han S, Kim T, Jeon YK, Hwang PG, Im S, Lee K, Kim JH, Kim D, Heo DS, Kim NK, Chung DH, Bang Y: Optimization of patient selection for gefitinib in non-small cell lung cancer by combined analysis of epidermal growth factor receptor mutation, K-ras mutation, and Akt phosphorylation. Clinical cancer research: an official journal of the American Association for Cancer Research 2006, 12:2538-44.

\section{FlOOOPrime}

26. Vivanco I, Rohle D, Versele M, Iwanami A, Kuga D, Oldrini B, Tanaka K, Dang J, Kubek S, Palaskas N, Hsueh T, Evans M, Mulholland D, Wolle D, Rajasekaran S, Rajasekaran A, Liau LM, Cloughesy TF, Dikic I, Brennan C, Wu H, Mischel PS, Perera T, Mellinghoff IK: The phosphatase and tensin homolog regulates epidermal growth factor receptor (EGFR) inhibitor response by targeting EGFR for degradation. Proceedings of the National Academy of Sciences of the United States of America 2010, 107:6459-64.

\section{FlOOOPrime}

27. Berns K, Horlings HM, Hennessy BT, Madiredjo M, Hijmans EM, Beelen K, Linn SC, Gonzalez-Angulo AM, Stemke-Hale K, Hauptmann M, Beijersbergen RL, Mills GB, van de Vijver Marc J, Bernards R: A functional genetic approach identifies the PI3K 
pathway as a major determinant of trastuzumab resistance in breast cancer. Cancer cell 2007, I 2:395-402.

\section{FIOOOPrime}

28. Stommel JM, Kimmelman AC, Ying $H$, Nabioullin R, Ponugoti $A H$, Wiedemeyer R, Stegh AH, Bradner JE, Ligon KL, Brennan C, Chin L, DePinho RA: Coactivation of receptor tyrosine kinases affects the response of tumor cells to targeted therapies. Science (New York, N.Y.) 2007, 3 1 8:287-90

\section{FlOOOPrime
RECOMMENDED}

29. Guix M, Faber AC, Wang SE, Olivares MG, Song Y, Qu S, Rinehart C, Seidel B, Yee D, Arteaga CL, Engelman JA: Acquired resistance to EGFR tyrosine kinase inhibitors in cancer cells is mediated by loss of IGF-binding proteins. The Journal of clinical investigation 2008, I I 8:2609-19.

\section{FlOOOPrime}

\section{RECOMMENDED}

30. Wong MH, Xue A, Julovi SM, Pavlakis N, Samra JS, Hugh TJ, Gill AJ, Peters L, Baxter RC, Smith RC: Cotargeting of epidermal growth factor receptor and PI3K overcomes PI3K-Akt oncogenic dependence in pancreatic ductal adenocarcinoma. Clinical cancer research: an official journal of the American Association for Cancer Research 2014, 20:4047-58.

31. Saura C, Bendell J, Jerusalem G, Su S, Ru Q, S de Buck, Mills D, Ruquet S, Bosch A, Urruticoechea A, Beck JT, Di Tomaso E, Sternberg DW, Massacesi C, Hirawat S, Dirix L, Baselga J: Phase Ib study of Buparlisib plus Trastuzumab in patients with HER2positive advanced or metastatic breast cancer that has progressed on Trastuzumab-based therapy. Clinical cancer research: an official journal of the American Association for Cancer Research 2014, 20:1935-45.

\section{FlOOOPrime \\ RECOMMENDED}

32. Villanueva J, Vultur A, Lee JT, Somasundaram R, Fukunaga-Kalabis M, Cipolla AK, Wubbenhorst B, Xu X, Gimotty PA, Kee D, SantiagoWalker AE, Letrero R, D'Andrea K, Pushparajan A, Hayden JE, Brown KD, Laquerre S, McArthur GA, Sosman JA, Nathanson KL, Herlyn M: Acquired resistance to BRAF inhibitors mediated by a RAF kinase switch in melanoma can be overcome by cotargeting MEK and IGF-IR/PI3K. Cancer cell 20I0, I 8:683-95.

\section{FlOOOPrime \\ RECOMMENDED}

33. Zmajkovicova K, Jesenberger V, Catalanotti F, Baumgartner C, Reyes G, Baccarini M: MEKI is required for PTEN membrane recruitment, AKT regulation, and the maintenance of peripheral tolerance. Molecular cell 20I3, 50:43-55.

\section{FlOOOPrime \\ RECOMMENDED}

34. Engelman JA, Chen L, Tan X, Crosby K, Guimaraes AR, Upadhyay R, Maira M, McNamara K, Perera SA, Song Y, Chirieac LR, Kaur R, Lightbown A, Simendinger J, Li T, Padera RF, García-Echeverría C, Weissleder R, Mahmood U, Cantley LC, Wong K: Effective use of PI3K and MEK inhibitors to treat mutant Kras GI2D and PIK3CA HI047R murine lung cancers. Nature medicine 2008, |4:|35|-6.

35. Posch C, Moslehi H, Feeney L, Green GA, Ebaee A, Feichtenschlager V, Chong K, Peng L, Dimon MT, Phillips T, Daud Al, McCalmont TH, LeBoit PE, Ortiz-Urda S: Combined targeting of MEK and PI3K/mTOR effector pathways is necessary to effectively inhibit NRAS mutant melanoma in vitro and in vivo. Proceedings of the National Academy of Sciences of the United States of America 2013, I I 0:40 I 5-20.

36. Lindholm EM, Krohn M, ladevaia S, Kristian A, Mills GB, Mælandsmo GM, Engebraaten O: Proteomic characterization of breast cancer xenografts identifies early and late bevacizumab-induced responses and predicts effective drug combinations. Clinical cancer research: an official journal of the American Association for Cancer Research 2014, 20:404-I2.

\section{FlOOOPrime
RECOMMENDED}

37. Murillo MM, Zelenay S, Nye E, Castellano E, Lassailly F, Stamp G, Downward J: RAS interaction with PI3K pIIO $\alpha$ is required for tumor-induced angiogenesis. The Journal of clinical investigation 2014, I24:360I-II.

38. Hähnel PS, Thaler S, Antunes E, Huber C, Theobald M, Schuler M: Targeting AKT signaling sensitizes cancer to cellular immunotherapy. Cancer research 2008, 68:3899-906.

39. Noh KH, Kang TH, Kim JH, Pai SI, Lin KY, Hung C, Wu T, Kim TW: Activation of Akt as a mechanism for tumor immune evasion. Molecular therapy: the journal of the American Society of Gene Therapy 2009, 17:439-47.

40. Parsa AT, Waldron JS, Panner A, Crane CA, Parney IF, Barry JJ, Cachola KE, Murray JC, Tihan T, Jensen MC, Mischel PS, Stokoe D, Pieper RO: Loss of tumor suppressor PTEN function increases B7-HI expression and immunoresistance in glioma. Nature medicine 2007, I 3:84-8.

\section{FlOOOPrime}

RECOMMENDED

4I. Song $M$, Chen D, Lu B, Wang C, Zhang J, Huang L, Wang X, Timmons CL, Hu J, Liu B, Wu X, Wang L, Wang J, Liu H: PTEN loss increases PD-LI protein expression and affects the correlation between PD-LI expression and clinical parameters in colorectal cancer. PloS one 2013, 8:e6582I

42. Marshall NA, Galvin KC, Corcoran AB, Boon L, Higgs $R$ Mills Kingston HG: Immunotherapy with PI3K inhibitor and Toll-like receptor agonist induces IFN- $\gamma+I L-I 7+$ polyfunctional $\mathrm{T}$ cells that mediate rejection of murine tumors. Cancer research 2012, 72:581-91.

\section{FlOOOPrime}

43. Ali K, Soond DR, Piñeiro R, Hagemann T, Pearce W, Lim EL, Bouabe $H$, Scudamore CL, Hancox T, Maecker H, Friedman L, Turner M, Okkenhaug K, Vanhaesebroeck B: Inactivation of PI(3)K p I I $0 \delta$ breaks regulatory T-cell-mediated immune tolerance to cancer. Nature 2014, 5 I 0:407-I I.

\section{FlOOOPrime}

44. Buonamici S, Williams J, Morrissey M, Wang A, Guo R, Vattay A, Hsiao K, Yuan J, Green J, Ospina B, Yu Q, Ostrom L, Fordjour P, Anderson DL, Monahan JE, Kelleher JF, Peukert S, Pan S, Wu X, Maira S, García-Echeverría C, Briggs KJ, Watkins DN, Yao Y, Lengauer C, Warmuth M, Sellers WR, Dorsch M: Interfering with resistance to smoothened antagonists by inhibition of the PI3K pathway in medulloblastoma. Science translational medicine 2010, 2:5I ra70.

\section{FlOOOPrime}

\section{RECOMMENDED}

45. Dienstmann R, Rodon J, Serra V, Tabernero J: Picking the point of inhibition: a comparative review of PI3K/AKT/mTOR pathway inhibitors. Molecular cancer therapeutics 20|4, I3:|021-31.

46. Brachmann SM, Kleylein-Sohn J, Gaulis S, Kauffmann A, Blommers Marcel J], Kazic-Legueux M, Laborde L, Hattenberger M, Stauffer F, Vaxelaire J, Romanet V, Henry C, Murakami M, Guthy DA, Sterker D, Bergling S, Wilson C, Brümmendorf T, Fritsch C, GarciaEcheverria C, Sellers WR, Hofmann F, Maira S: Characterization of the mechanism of action of the pan class I PI3K inhibitor NVP-BKMI20 across a broad range of concentrations. Molecular cancer therapeutics 2012, I I:|747-57.

47. Vora SR, Juric D, Kim N, Mino-Kenudson M, Huynh T, Costa C, Lockerman EL, Pollack SF, Liu M, Li X, Lehar J, Wiesmann M, Wartmann M, Chen Y, Cao ZA, Pinzon-Ortiz M, Kim S, Schlegel R, Huang A, Engelman JA: CDK 4/6 inhibitors sensitize PIK3CA 
mutant breast cancer to PI3K inhibitors. Cancer cell 20I4, 26:136-49.

\section{FlOOOPrime}

48. Elkabets M, Vora S, Juric D, Morse N, Mino-Kenudson M, Muranen T, Tao J, Campos AB, Rodon J, Ibrahim YH, Serra V, RodrikOutmezguine V, Hazra S, Singh S, Kim P, Quadt C, Liu M, Huang A, Rosen N, Engelman JA, Scaltriti M, Baselga J: $\mathbf{m T O R C I}$ inhibition is required for sensitivity to PI3K pIIO $\alpha$ inhibitors in PIK3CAmutant breast cancer. Science translational medicine 2013, 5:196ra99.

\section{FlOOOPrime}

RECOMMENDED

49. Chandarlapaty S, Sawai A, Scaltriti M, Rodrik-Outmezguine V, Grbovic-Huezo O, Serra V, Majumder PK, Baselga J, Rosen N: AKT inhibition relieves feedback suppression of receptor tyrosine kinase expression and activity. Cancer cell 20 I I, I9:58-7 I.

\section{FlOOOPrime \\ RECOMMENDED}

50. Garrett JT, Olivares MG, Rinehart C, Granja-Ingram ND, Sánchez V, Chakrabarty A, Dave B, Cook RS, Pao W, McKinely E, Manning HC, Chang J, Arteaga CL: Transcriptional and posttranslational upregulation of HER3 (ErbB3) compensates for inhibition of the HER2 tyrosine kinase. Proceedings of the National Academy of Sciences of the United States of America 201 I, I 08:502 I-6.

\section{FlOOOPrime \\ RECOMMENDED}

5I. Chakrabarty A, Sánchez V, Kuba MG, Rinehart C, Arteaga CL: Feedback upregulation of HER3 (ErbB3) expression and activity attenuates antitumor effect of PI3K inhibitors. Proceedings of the National Academy of Sciences of the United States of America 2012, 109:2718-23.

\section{FlOOOPrime \\ RECOMMENDED}

52. O'Reilly KE, Rojo F, She Q, Solit D, Mills GB, Smith D, Lane H, Hofmann F, Hicklin DJ, Ludwig DL, Baselga J, Rosen N: mTOR inhibition induces upstream receptor tyrosine kinase signaling and activates Akt. Cancer research 2006, 66:1500-8.

\section{FlOOOPrime
RECOMMENDED}

53. Britschgi A, Andraos R, Brinkhaus $H$, Klebba I, Romanet $V$, Müller $U$, Murakami M, Radimerski T, Bentires-Alj M: JAK2/STAT5 inhibition circumvents resistance to $\mathrm{PI} / \mathrm{K} / \mathrm{mTOR}$ blockade: a rationale for cotargeting these pathways in metastatic breast cancer. Cancer cell 2012, 22:796-8II.

54. Huw L, O'Brien C, Pandita A, Mohan S, Spoerke JM, Lu S, Wang Y, Hampton GM, Wilson TR, Lackner MR: Acquired PIK3CA amplification causes resistance to selective phosphoinositide 3-kinase inhibitors in breast cancer. Oncogenesis 2013, 2:e83.

55. Wagle N, Grabiner BC, Van Allen, Eliezer M, Amin-Mansour A, Taylor-Weiner A, Rosenberg M, Gray N, Barletta JA, Guo Y, Swanson SJ, Ruan DT, Hanna G], Haddad RI, Getz G, Kwiatkowski DJ, Carter SL, Sabatini DM, Jänne PA, Garraway LA, Lorch JH: Response and acquired resistance to everolimus in anaplastic thyroid cancer. The New England journal of medicine 2014, 371:1426-33.

\section{FIOOOPrime}

56. Hassan B, Akcakanat A, Sangai T, Evans KW, Adkins F, Eterovic AK, Zhao H, Chen K, Chen H, Do K, Xie SM, Holder AM, Naing A, Mills GB, Meric-Bernstam F: Catalytic mTOR inhibitors can overcome intrinsic and acquired resistance to allosteric mTOR inhibitors. Oncotarget 2014, 5:8544-57.

57. Carracedo A, Ma L, Teruya-Feldstein J, Rojo F, Salmena L, Alimonti A, Egia A, Sasaki AT, Thomas G, Kozma SC, Papa A, Nardella C, Cantley LC, Baselga J, Pandolfi PP: Inhibition of mTORCI leads to
MAPK pathway activation through a PI3K-dependent feedback loop in human cancer. The Journal of clinical investigation 2008, I | 8:3065-74.

\section{FlOOOPrime}

\section{RECOMMENDED}

58. Serra V, Scaltriti M, Prudkin L, Eichhorn PJA, Ibrahim YH, Chandarlapaty S, Markman B, Rodriguez O, Guzman M, Rodriguez S, Gili M, Russillo M, Parra JL, Singh S, Arribas J, Rosen N, Baselga J: PI3K inhibition results in enhanced HER signaling and acquired ERK dependency in HER2-overexpressing breast cancer. Oncogene 20II, 30:2547-57.

59. Serra V, Eichhorn Pieter JA, García-García C, Ibrahim YH, Prudkin L, Sánchez G, Rodríguez O, Antón P, Parra J, Marlow S, Scaltriti M Pérez-Garcia J, Prat A, Arribas J, Hahn WC, Kim SY, Baselga J: RSK3/ 4 mediate resistance to PI3K pathway inhibitors in breast cancer. The Journal of clinical investigation 2013, I 23:255 I-63.

\section{FlOOOPRime
RECOMMENDED}

60. Liu P, Cheng H, Santiago S, Raeder M, Zhang F, Isabella A, Yang J, Semaan DJ, Chen C, Fox EA, Gray NS, Monahan J, Schlegel R, Beroukhim R, Mills GB, Zhao JJ: Oncogenic PIK3CA-driven mammary tumors frequently recur via PI3K pathwaydependent and PI3K pathway-independent mechanisms. Nature medicine 201 I, 17: I I 16-20.

\section{FlOOOPrime}

6I. Muellner MK, Uras IZ, Gapp BV, Kerzendorfer C, Smida M, Lechtermann $\mathrm{H}$, Craig-Mueller N, Colinge J, Duernberger G, Nijman Sebastian MB: A chemical-genetic screen reveals a mechanism of resistance to PI3K inhibitors in cancer. Nature chemical biology 20II, 7:787-93.

62. Ilic N, Utermark T, Widlund HR, Roberts TM: PI3K-targeted therapy can be evaded by gene amplification along the MYCeukaryotic translation initiation factor 4E (elF4E) axis. Proceedings of the National Academy of Sciences of the United States of America 20II, 108:E699-708.

\section{FlOOOPrime}

63. Muranen T, Selfors LM, Worster DT, Iwanicki MP, Song L, Morales FC, Gao S, Mills GB, Brugge JS: Inhibition of PI3K/ mTOR leads to adaptive resistance in matrix-attached cancer cells. Cancer cell 2012, 21:227-39.

\section{FlOOOPrime} RECOMMENDED

64. Juvekar A, Burga LN, Hu H, Lunsford EP, Ibrahim YH, Balmañà J, Rajendran A, Papa A, Spencer K, Lyssiotis CA, Nardella C, Pandolfi PP, Baselga J, Scully R, Asara JM, Cantley LC, Wulf GM: Combining a PI3K inhibitor with a PARP inhibitor provides an effective therapy for BRCAI-related breast cancer. Cancer discovery 2012, 2:1048-63.

65. González-Billalabeitia E, Seitzer N, Song SJ, Song MS, Patnaik A, Liu X, Epping MT, Papa A, Hobbs RM, Chen M, Lunardi A, Ng C, Webster KA, Signoretti S, Loda M, Asara JM, Nardella C, Clohessy JG, Cantley LC, Pandolfi PP: Vulnerabilities of PTENTP53-deficient prostate cancers to compound PARP-PI3K inhibition. Cancer discovery 2014, 4:896-904.

66. Ibrahim YH, García-García C, Serra V, He L, Torres-Lockhart K, Prat A, Anton P, Cozar P, Guzmán M, Grueso J, Rodríguez O, Calvo MT, Aura C, Díez O, Rubio IT, Pérez J, Rodón J, Cortés J, Ellisen LW, Scaltriti M, Baselga J: PI3K inhibition impairs BRCA I/2 expression and sensitizes BRCA-proficient triple-negative breast cancer to PARP inhibition. Cancer discovery 20I2, 2:1036-47. 